\title{
The oil crisis and South Africa - A comparison with the world situation
}

\author{
D.J. Kotzé \\ Institute for Energy Studies, Rand Afrikaans University, Johannesburg
}

Address delivered by D.J. Kotzé, at the Congress of The Building In-

dustries Federation of South Africa, Johannesburg, 22 October 1979.

\begin{abstract}
Energy as a strategic resource has become a crucial world issue, to sustain future economic growth and survivat. The world depends for $95 \%$ of its total energy demand, on fossil fuel, supplies of which are limited, while world energy demand is increasing steadily along with population and economic growth. The West depends heavily on oil from the Middle East, and this has placed OPEC countries in a position to demand a twentyfold increase in crude oil prices in nine years. Alternative energy sources are discussed, but the world is still heading for a crisis due to imbalance between energy supply and demand. The energy situation in South Africa differs somewhat because local coal provides $\mathbf{8 0} \%$ of total energy requirements, and stringent conservation measures have achieved large reductions in oil consumption, while uranium, electricity generation and oil-from-coal technologies make the country less vulnerable than most other western countries. S. Afr. J. Bus. Mgmt 1980, 11: 50-53
\end{abstract}

Energie as 'n strategiese hulpbron het wêreldwyd krities geword, om toekomstige ekonomiese groei en oorlewing te verseker. Vir $95 \%$ van sy totale energieverbruik is die wèreld afhanklik van fossielbrandstof, waarvan voorrade beperk is, terwy! die wêreldvraag na energie steeds met bevolkings- en ekonomiese groei styg. Die Weste moet na die Midde-Ooste opsien vir olie, en dit hel OPEC-lande in staat gestel om ruoliepryse in nege jaar twintigvoudig te verhoog. Alternatiewe energiebronne word bespreek, maar die wèreld stuur steeds af op ' $n$ krisis weens wanbalans tussen energievraag en aanbod. Die energiesituasie in Suid-Afrika verskil ietwat omdat plaaslike steenkool $80 \%$ van totale energie benodig, verskaf, terwyl streng besparingsmaatreels groot vermindering in olieverbruik meegebring het, en uraan-, elektrisiteit- en olie-uitsteenkool-tegnologieè die land minder kwesbaar maak as meeste ander Westerse lande.

S.-Afr. Tydskr. Bedryfsl. 1980, 11: 50-53
Energy has become one of the most urgent and decisive issues of our times. Why this preoccupation with energy? In the first instance, because energy is indispensable to most forms of human activity, be they industrial, agricultural, military, or family life. As energy forms such a vital input to our everyday existence, it is imperative that energy should be available in strategically guaranteed quantities and at reasonable prices to sustain all forms of economic and other growth at all times.

However, while previously energy was cheap and abundant, the position has changed drastically in recent years and at present there is grave concern throughout the world over the continued availability of all forms of energy; so much so that lack of energy and food are today considered the two major problems facing the world.

Secondly, we know that the world depends on fossil fuel such as coal, oil and natural gas for no less than $95 \%$ of the total world energy demand. ${ }^{1}$ The world has, therefore, become almost completely dependent upon those resources, supplies of which are limited and finite and must someday be depleted, in contrast to such inexhaustible forms of energy such as solar, wind, tidal and hydro-electric energy.

A third cause of this state of concern is the steady increase, during the past few decades, in world energy demand. The two main factors underlying growth in demand for energy are, firstly, population growth and, secondly, economic growth. It is doubtful whether we can exert a significant influence on these two major underlying growth factors.

We also know that there is a very close but complex relationship between energy consumption and economic development. The greater the energy consumption of a country, the higher the standard of living, the degree of economic development, productive capacity or ability of that country. Energy is, in fact, not only a prerequisite for economic growth, but also a consequence thereof. South Africa ranks sixteenth in the world on energy consumption which, incidentally, is approximately the same position it occupies in the economic ranks of the world.

\section{Different forms of energy}

Considering the contributions of the different forms of energy to the world total, one observes that since the beginning of this century the relative contribution of oil and gas to the total has increased while that of coal has decreased - so much so that the two sister fuels today

Director, Institute for Energy Studies, 
provide almost two-thirds of the energy requirements of the world. As a result of over-production and low prices of oil, coal was replaced and during this period the free world became absolutely dependent on cheap imported crude oil. This dependence on oil explains the uproar which resulted from the unilateral price increase of oil by the Arab countries in 1973.

We know that the greatest part (approximately twothirds) of proven world oil reserves is found in the Middle East. ${ }^{2}$ Therefore, the West is at present almost completely dependent on the Middle East for its oil and consequently for its energy needs. In contrast, the East is to a great extent self-sufficient in energy.

Several authoritative international studies (the latest one by the World Energy Conference - as recently as in September $1978^{3}$ ) bear the conclusion that if future trends in world oil demand are considered in relation to available oil reserves, world demand of oil will exceed supply before the middle of this decade. Under these circumstances the OPEC countries (i.e. the Organization for Petroleum Exporting Countries) realized their strength as a powerful producer in a sellers' market $-\mathbf{a}$ fact which resulted in the price of crude oil rising from less than $\$ 1,50$ a barrel in 1970 to approximately $\$ 33$ a barrel in 1979, if one quotes the current average spot market price - a twentyfold increase in nine years.

The question arises: To what degree can alternative energy resources ease the pressure on oil in the short term until technology can make a greater contribution? Careful analysis of all the different options reveals that the future prospects are not as favourable as some people believe. At one stage it was hoped that nuclear power would rush to the assistance of mankind, but even the most enthusiastic proponents of nuclear power will admit that this form of energy is not free of problems. The universal application of nuclear power faces problems such as the choice of unproven technologies, widely spread danger of pollution, immense cost escalations and the long lead times required to replace conventional power stations. The so-called fast breeder reactors and fusion reactors are still at the research stage. In this respect it is illuminating to quote Sir Samuel Curran who states that 'from the time that a new energy source has been discovered by the scientist until it is making a reasonably substantial contribution to the national needs, an interval of some 30 or so years must elapse'. Nuclear power itself is a good example of this. No matter what the favourable results of technological development are, and it is reasonable to accept that break-throughs will occur, the energy problem will reach its climax within the next five years - a period too short for technology to be able to influence the situation to any great extent.

Other alternatives, such as solar, wind and tidal energy, fuel cells, and heat pumps, are also still largely in the research stage and considerable technological development is necessary before these possibilities can be utilized universally. The indications are that energy from these sources will be very expensive and that it will take a long time to establish these schemes in practice on a significant scale.

\section{Heading for the real energy crisis}

The following conclusion is obvious: The world is heading for a crisis situation and man has very little control over the inherent factors leading to this situation. The real or true energy crisis differs from the oil crisis of 1973 and 1979 in one important respect - namely that this crisis is not politically inspired as those in 1973 and 1979 were, but that it has at its roots an imbalance between world demand and supply of energy.

Some elements in this sombre picture can already be identified with a reasonable degree of certainty.

- Energy shortages will be world-wide. A rush will develop for all remaining supplies of fossil fuel and countries will compete with one another for the limited available resources.

- The Organization for Petroleum Exporting Countries will become more and more militant in its demands, drastically increasing the price of oil: the days of cheap energy are forever gone. ${ }^{4}$

- Since oil is such an important constituent of the energy diet of the world and energy is such a necessary prerequisite for economic activity, it is obvious that the price will be paid in terms of economic development. Most countries will experience chronic balance of payment deficits; external trade will decrease; unemployment will be rampant, with consequent economic and social regression.

- Coal is the only form of energy which can bring a degree of relief in the short term, because remaining supplies of this energy source are still reasonably large. However, massive problems are associated with the exploitation of this raw material on the scale required, including the availability of enormous reserves of capital; the maintenance of required environmental standards; the recruiting and training of adequate manpower; and the shortening of the long delivery times of mining equipment.

\section{Energy in South Africa}

Against this rather alarming backdrop, let us now consider the energy position in South Africa in an attempt to map out our priorities.

Until fairly recently energy was not regarded as a severe problem in South Africa. We have much coal, formerly oil was cheap, we did not have exceptional balance of payment problems and the price of gold was rising. Recently the situation has of course changed and we are increasingly forced to keep abreast of developments in the energy sphere.

South Africa is not as dependent on oil as other countries in the world, coal providing approximately $80 \%$ of our total energy requirements. This can be ascribed to the fact that the country is blessed with large and relatively cheap deposits of coal. As a result of this, our electricity and metallurgical industries, and also our rail transport sector, depend almost exclusively on coal as a primary energy source. This explains why the oil crisis of 1973 did not affect us as drastically as it did many other countries; although, admittedly, it did create problems for us too. Consequently, we are experiencing an oil crisis rather than an energy crisis in South Africa, in contrast to the 'situation in the rest of the world.

As already stated, several authoritative international studies undertaken in the recent past bear the conclusion 
that world demand for oil will exceed available supply by the middle of this decade. Some of these investigations have found that, depending upon certain conditions, for instance the production levels attained in Saudi Arabia, the imbalance can occur as early as in 1981. All these studies were done prior to the recent revolution in Iran. The Iranian revolution and cessation of exports resulted in the world imbalance being brought forward by a number of years. Although Iran is a substantial exporter of oil, her exports of about 5 million barrels per day are small in relation to total world production and the current oil shortfall is estimated at no more than $5 \%$ of total world supply. Nevertheless, prices, especially those on the spot market, immediately shot upwards and spot market prices of as high as $\$ 50$ a barrel were recorded recently. There are also indications of collusion between the member states of OPEC to keep total supply just below world demand so that they are in a position to manipulate prices at will. It is clear that there is potential for further drastic increases in the price of oil.

In the past, prices of oil on the spot market followed the official OPEC prices fairly constantly but since the reduction in Iranian exports, spot market prices increased drastically and they are now almost double the official OPEC prices.

The sharp increase in spot market prices was caused partly by the fact that South Africa and Israel, who were formerly supplied by Iran, now had to turn to the spot market for their supplies and partly as a result of stockpiling by consumer countries in the Northern Hemisphere in anticipation of the northern winter of $1979-80$.

\section{The world economy}

The high prices of oil are bound to have significant repercussions on the international economic outlook. In general, the danger exists that an economic slump might recur in much the same way as in 1974 and 1975, after the oil price hike of 1973. Inflationary pressure will increase. It can be expected that internal economies, as well as the world trade, will undergo structural changes.

\section{Short term prospects}

In the meantime Iran resumed exports, and it is estimated that she currently exports about $31 / 2$ million barrels per day. It is, however, unlikely that exports will reach the levels attained prior to the revolution.

The likelihood of further political instability in Iran is not excluded. It is even possible that political unrest may occur in Iraq and Saudi Arabia.

The oil industry nevertheless estimates that, barring unforeseen circumstances, spot market prices of oil may stabilize at about $\$ 27$ to $\$ 30$ a barrel by April or May of 1980. Thereafter it may even decline slightly towards the end of 1980 .

\section{The oil crisis and South Africa}

South Africa specifically was hard hit by these developments as we have in recent years become very dependent upon Iran as a supplier of crude oil. Therefore, when she lost her traditional Iranian source of supply, South Africa had to turn to the spot market and had to suffer increased prices and a heavy burden on her balance of payments. It would appear that South Africa at present obtains almost all of her requirements on the spot market.

It had been clear for some time that the country could not afford these high prices for oil and the measures announced by the Minister of Economic Affairs on June 7, 1979 were not entirely unexpected. Furthermore, it is doubtful whether prices and availability of petroleum products in South Africa up to now have reflected our rather precarious supply position vis- $\grave{a}$-vis the rest of the world.

The drastic increase in the price of fuel $(40 \%)$, have had widespread economic repercussions. Some of physical restriction measures, such as speed limits and trading hours have, of course, since been relaxed.

Nevertheless, the first effect of the drastic increase in fuel cost was a significant reduction in the demand for fuel. Indications are at present that the demand for petrol may have decreased by as much as $20 \%$ since the increase in price.

\section{The motor industry}

The higher prices of fuel will also affect the motor industry negatively. Some of the major motor manufacturers are already considering a three-day work week. A swing to smaller, more economical cars can also be expected, and recent sale figures indicate that it is already taking place.

A section of the motor industry which will be affected directly by changed driving habits of motorists, is the motor components sector. Less driving will mean less wear on cars. Panel beaters will be affected adversely. Some of the 5000 Black drive-way attendants will also lose their jobs or at least face reduced income.

It has been estimated that the contribution of the motor industry and its satellites, such as the components industry, the motor trade and garages, to the Gross Domestic Product, is even larger than that of agriculture. It means, therefore, that the drastic decrease in fuel consumption will affect the general economy over a very wide front. Present indications are that the growth target of $4 \%$ in the South African economy for 1979 will probably not be realized.

Under these circumstances, the relief package to the motor industry, recently announced by the Minister of Industries, Trade and Consumer Affairs, came as no surprise.

\section{Inflation}

Price rises lead to further price rises and it appears that the biggest single economic headache with which the government will have to contend over the next few months will be the high rate of inflation.

The effect of a price rise of oil is generally twofold: Oil is, firstly, a very important intermediary raw material in many industries and, secondly, in the final consuming category oil is used directly as a fuel.

All industries using petroleum-based raw materials, such as the textile, plastics, pharmaceutical, building, paint, motor and many other industries, will have to adjust their prices to accommodate such a rise in raw material cost.

The Minister of Economic Affairs estimated that the 
fuel price increase will cause the rate of inflation to rise by $2 \%$. There are indications that this may be too low. Nevertheless, accepting a $2 \%$ rise, it must be expected that the rate of inflation will reach $15 \%$ by the end of 1979.

\section{Expenditure}

The higher fuel prices are therefore expected to lead to increases in prices of many other commodities such as food, bus fares, motor cars and even houses. In general, this must lead to a decrease in disposable income of people.

It has been found traditionally that private consumption expenditure on fuel seldom exceeds $8,5 \%$ of total consumption expenditure. A decrease in expenditure, a decrease in saving, coupled with increased inflation, must lead to a lowering of living standards.

Over the longer term it may be expected that life styles of people will change. A swing from larger to smaller cars and a swing away from private to public transport will take place. Even the tourist industry stands to be affected as the ordinary man will be forced to limit his nonessential expenditure.

\section{Summary, findings}

From the aforementioned it should be clear that energy will be the paramount problem facing the major industrial powers for the remainder of this century. Its repercussions will resound in many areas - economic, social and political - and many facets of the existence of the ordinary man will be affected. No country - not even South Africa - can isolate itself from these events.

However, in spite of the fact that South Africa will be affected adversely in the short term by the oil crisis, there are many factors working in her favour over the longer term.

First and foremost, we are fortunate that we depend upon oil as a source of energy for less than one-fifth of our total energy needs. The latest round of price increases and other supplementary fuel restriction measures had the effect of reducing oil's contribution to total energy demand to below $20 \%$. Our corresponding high reliance on coal as a source of energy is unique for a country which has reached the stage of development of South Africa. At the present moment, apart from two small hydro-electric stations, coal supplies the energy for almost all the electricity generated in South Africa.

As far as uranium is concerned, South Africa is ranked as the third biggest producer in the Western World, having the second highest reserves, and in coal, we rank sixth in production and fifth in reserves.

South Africa has a sophisticated electricity generation and transmission system. Covering just over $4 \%$ of the area of the continent of Africa and having less than $6 \%$ of its total population, South Africa supplies more than $50 \%$ of the total electricity generated on the continent.

South Africa is the only country in the world possessing a commercially viable oil-from-coal industry. Fur- thermore, a significant portion of our local oil demand will be satisfied from indigenous coal when all three SASOLS are in production by 1984 . Local consumption of imported oil will already begin to decline from 1980 onwards as a result of SASOL II coming on stream. In fact, according to present indications, consumption of foreign oil in 1979 may well already be less than in 1978 on acount of the higher prices and other fuel restriction measures. The year of 1978 may well go down in our history as the year during which the consumption of foreign oil reached an all time high in South Africa.

South Africa is one of only a few countries in the world which has succeeded in drastically curtailing consumer demand for oil since the first oil crisis of October 1973. The reduction of our dependence upon imported crude oil has not been equalled anywhere in the world.

South Africa embarked on a crude oil stockpiling programme, using worked out coal mines for storage, and had almost completed this programme prior to the drastic increases in the world prices of crude oil. For an oilimporting country, South Africa's strategic inventory of crude oil, expressed as a ratio of normal demand, has not been equalled anywhere else in the world.

The Southern Oil Exploration Corporation (SOECOR) has been co-ordinating a concerted search for oil and gas on land and offshore for the last number of years. Various traces of oil and gas have so far been found.

South African scientists have succeeded in developing a new process for the enrichment of uranium which may be unlocking the second most important South African primary energy resource for the future commercial use.

A National Committee for Energy Research under the direction of the CSIR was established a number of years ago to co-ordinate all the diverse research efforts in progress in the field of energy.

One of the effects of the high prices of oil is that the production of alcohol - both ethanol from agricultural products and methanol from coal - is now reaching economic viability.

The nett result of the foregoing is that it may even be possible to think in terms of decided South African comparative advantages in the production of energy-intensive products, such as steel and aluminium.

In the last instance, South Africa is in the unique position that her exports of precious metals and minerals will, to a large extent, offset the effect of the high oil price on her economy.

\section{References}

1 Dept. of Planning and the Environment, 1975. Energy trends in the world with special reference to South Africa. Pretoria: Dept. of Planning.

2 British Petroleum, Statistical review of the world oil industry. 1978. BP. Brittannic House, London.

3 World Energy Conference, Conservation Committee, 1978. World Energy: Looking ahead to 2020. IPC Science and Technology Press, Guildford, UK.

4 British Petroleum, 1979. Oil Crisis - Again? A brief by the policy review unit of BP Oil Company, Sept. 1979. BP, Brittannic House, London. 